\title{
Sovereign credit ratings, capital flows and financial sector development in Emerging markets ${ }^{\#}$
}

\author{
Suk-Joong Kim \\ Eliza $\mathrm{Wu}^{*}$
}

School of Banking and Finance, University of New South Wales, Sydney, NSW 2052, Australia.

\begin{abstract}
How does the sovereign credit ratings history provided by independent ratings agencies affect domestic financial sector development and international capital inflows to emerging countries? We address this question utilizing a comprehensive dataset of sovereign credit ratings from Standard and Poor's from 1995-2003 for a cross-section of 51 emerging markets. Within a panel data estimation framework, we examine financial sector development and the influence of sovereign credit ratings provision, controlling for various economic and corporate governance factors identified in the financial development literature. We find strong evidence that our sovereign credit rating measures do affect financial intermediary sector developments and capital flows. We find that i) long-term foreign currency sovereign credit ratings are important for encouraging financial intermediary development and for attracting capital flows. ii) Long-term local currency ratings stimulate domestic market growth but discourage international capital flows. iii) Short-term ratings (both foreign and local currency denominated) retard all forms of financial developments and capital flows. There are important implications in this research for policy makers to encourage the provision of longerterm credit ratings to promote financial development in emerging economies.
\end{abstract}

JEL classification: E44, E65, F33, F34, G15

Keywords: Emerging markets, credit ratings, transparency, financial development, capital flows and sovereign risk

\footnotetext{
\# We thank an anonymous referee as well as Menzie Chinn for helpful comments which improved this paper.

* Corresponding author. Email: e.wu@unsw.edu.au; Tel.: +61-2-9385-5889; Fax: +61-2-9385-6347.
} 


\section{Introduction}

Financial crises in the past decade have drawn a great debate about the role of financial flows in emerging market economies. It is generally believed that improving a country's transparency, information control, financing costs and sovereign risk levels is expected to increase international capital inflows and improve the general level of development in financial markets and their financial integration with world capital markets. Reinhart and Rogoff (2004) find that the flows of capital from developed to emerging countries are influenced by, among other factors, sovereign default risk, which is typically measured by sovereign credit ratings. Whilst episodes of financial crises have shown that these ratings fail in predicting sudden changes within emerging markets we hypothesize that they have significant information value to improve institutional quality for facilitating long-run financial and economic development. To our best knowledge, this has not been investigated to date. Accordingly, our primary contribution is to fill this surprising void and investigate the influence of sovereign ratings on the development of financial intermediary sectors in emerging markets and on the nature of international capital inflows.

Previous studies have found sovereign credit ratings across countries to encapsulate various fundamental aspects of a country's debt history and macroeconomic strength such as the amount of debt outstanding, GDP per capita, economic growth, inflation and debt repayment ability (see inter alia Cantor and Packer, 1996; Afonso, 2003; and Mora, 2006). As such, sovereign credit ratings are deemed to be a reference measure of country risk. Much of the literature has focused on its short-term information (predictive) content for financial market returns, interdependence and crises (see for example, Kaminsky and Schmukler, 1999; Brooks et al., 2004; Mora, 2006; Gande and Parsley, 2005; and Ferreira and Gama, 2007). It is conceivable that there are many risk factors simultaneously influencing a country's credit rating including political and other expropriation risk, inflation, exchange rate volatility and controls, the country's industry composition, economic viability and sensitivity to global economic shocks. This arguably makes sovereign credit ratings a good proxy for the degree of 
transparency and future country risk. ${ }^{1}$ In support of this view, Erb, Harvey and Viskanta (1999) find a high correlation between the country credit ratings and the sovereign bond yield spreads of emerging markets.

Financial development is important for financial intermediation and the efficient allocation of capital within global economies. It is clearly a crucial element to the overall economic development of emerging capital markets. The extent to which financial intermediation is developed and proceeds in emerging capital markets is often hampered by domestic political tensions or a lack of macroeconomic and government transparency. There exists a well-established literature assessing financial development, the bank or market orientation of financial systems and particularly their promotion of economic development and growth at the aggregate, industry and firm level (see inter alia Greenwood and Jovanovic, 1990; King and Levine, 1993; Levine, 1997; Levine and Zervos, 1998;, Rajan and Zingales, 1998; Beck et al., 2000; Carlin and Mayer, 2003; Claessens and Laeven, 2003; Fisman and Love, 2004; and Ndikumana, 2005). In this vein, Demirguc-Kunt and Maksimovic (2002) show a positive link between financial development and firms’ access to external finance and Wurgler (2000) highlights financial development and capital allocation efficiency.

Motivated by its key role in economic development, there is also a burgeoning literature on the determinants of financial development - covering institutional, economic, political, religious, cultural and legal domains (La Porta et al. (1999), Beck et al. (2000), Stulz and Williamson (2003), Claessens and Laeven (2003), Rajan and Zingales (2003), and Chinn and Ito (2006)). This literature has largely focused on stock market developments. Little is known about the precursory developments of public and private debt sectors in the broader evolution from bank-based to market based financial structures in emerging economies. Thus, we address this deficiency in the existing literature by examining the extent to which the observed differences in development levels within different domestic financial intermediary sectors can be accounted for by an obvious but so far overlooked candidate that encapsulates various existing explanations, namely the sovereign credit ratings history provided by rating

\footnotetext{
${ }^{1}$ In a similar spirit, Morgan (2002) in studying banking industries interpreted a greater dispersion of bond ratings as greater opaqueness of banks.
} 
agencies. The advantage of studying sovereign credit ratings is that sovereigns and their primary influences on a country's institutions and policies are central to the foundations of financial market and economic development. In effect, we explore the relationships between the development in different forms of financial intermediation and a country's perceived willingness and ability to repay its debts, on which financial stability depends. This is important not only because international lenders often look to sovereigns to provide implicit or explicit payment guarantees to private borrowers and the sovereigns' financial positions in both local and foreign currencies play a crucial role in this regard, but also, private debt issuers' credit rating is bounded from above by their respective country's sovereign ratings.

Bank-based financial intermediation continues to dominate public security markets, if present, in emerging market finance but financial systems have a tendency to become more market based as economies develop. It is conceivable that the extent to which different financial sectors are developed differ across countries. The national differences in financial sector developments pose a useful framework for assessing how independent rating agencies may influence financial development and at the same time, financial flows to emerging markets - a key requirement for stable financial systems. An emerging market's domestic financial development and international capital flows are inexplicably intertwined so it is important to examine the influence of sovereign ratings on both aspects in this study.

We proceed to construct multiple measures of domestic financial sector development to capture and better understand how different aspects of the emerging financial system are affected. We seek to shed light on the elements of financial underdevelopment in emerging financial markets, where independent ratings agencies may help. In addition, we examine the influence of the ratings on attracting international capital and thus domestic financial sector development. Unlike the majority of existing studies looking at a combination of developed and developing countries, we focus exclusively on emerging markets to minimize the variation in financial structure and corporate governance standards which may mask underlying relationships. We utilize a panel data framework with 51 emerging market countries and 9 years over the period 1995-2003 to examine the channels through which different types of sovereign credit ratings (on long- and short-term and local and foreign 
currency denominated sovereign debts ${ }^{2}$ ) may affect financial development and international capital flows (international banking, foreign direct investment and portfolio flows).

We find strong evidence that our ratings measures affect financial sector developments and international capital flows. The specific findings are summarized as follows. i) Foreign currency long-term ratings proved to be the most important stimulus for international capital flows. All three forms of capital inflows (FDI, banking and portfolio) were significantly increased as foreign currency long-term ratings of emerging market sovereigns improved. A flow on effect on the domestic market development is felt most noticeably in the bond market sector where a significant positive association is found. In addition, there is some evidence that long-term foreign currency ratings contribute to changes in financial structure as it creates a trade- off between developments of the stock market on the one hand and the banking sector and the bond markets on the other.

ii) Local currency long-term ratings provide conflicting influences on international capital flows and domestic financial sector developments. On the one hand, they stimulated the developments of domestic stock and banking sectors, but they had detrimental impact on international capital flows. We argue that many emerging market sovereigns provide safety nets for financial sectors (e.g. lenders of last resort in the banking sector and management of market stabilization funds in stock and bond markets) and an improvement in sovereigns' local currency fiscal positions adds to market stability and hence a stimulus to market growth. However, as domestic markets develop more domestic currency funds would be supplied and this reduces sovereigns' reliance on foreign currency capital in financing domestic currency expenditures, thus lessening the impact of 'original sin'.

iii) We find detrimental impacts of short-term ratings in both foreign and domestic currency ratings. Improvements in short-term ratings, in general, deter international capital inflows and hamper domestic financial market developments. We argue that an improvement in short-term ratings encourages sovereigns to switch from long-term financing to short-term financing which potentially raises liquidity risks, leading to a deterioration in capital inflows

\footnotetext{
${ }^{2}$ Local and foreign currency sovereign credit ratings are largely based on the same factors but the latter gives more focus to balance of payments, political risk, economic policies and global integration and reflects a country's capacity to meet debt obligations denominated in foreign currency terms (see Brooks et al. (2004)).
} 
and long-term financial development potentials. The obvious implication of this finding is for emerging market policy makers to encourage the provision of public credit ratings for longterm debt denominated in both domestic and foreign currencies.

Thus, we make important policy contributions particularly given the recent spotlight shone on independent credit rating agencies to provide credit risk ratings for financial institutions and economies as part of the Basle II accord. This study is also relevant for the international investment community relying on credit ratings guidance in their financial decision making. The rest of this paper is organized as follows. Section 2 will set up the theoretical motivations for this study. Section 3 will discuss the data used and relevant modeling issues are discussed in Section 4. Section 5 will document the empirical results and conclusions are presented in Section 6.

\section{Theoretical motivations}

One of the key functions of financial sectors in emerging financial systems is the matching of savers (investors) and borrowers (security issuers) within a capital market. The hallmarks of a developed financial system include an effective legal system that enforces the protection for property rights and financial contracting; transparent accounting and disclosure systems; a good reputation for sound policymaking (supportive of financial markets and their development) and macroeconomic management; and adequate regulatory infrastructure and institutional quality (see inter alia, LaPorta et al., 1997, 1998; Beck et al., 2000; Carlin and Mayer, 2003; and Rajan and Zingales, 2003). Since credit ratings naturally encapsulate some

of the powerful incentives for financial development and are likely to influence financial decisions, it is important to investigate whether independent sovereign credit ratings can (either directly or indirectly) influence how different financial sectors carry out the resource allocation function. We question whether different types of credit ratings guidance (foreign vs. local currency, long-term vs. short-term nature) will have different effects on development in different sectors (banking, bonds and equity). 
Existing theories relating to financial structure and economic development, postulate the relevance of information disclosure to the effective provision of finance. Boyd and Smith (1998) argued theoretically that since capital is scarce in developing economies, monitoring costs should be low relative to the cost of capital. Therefore, bank finance being intensive in monitoring, is preferable in the early stages of economic development. In this vein, credit ratings can directly reduce monitoring $\operatorname{costs}^{3}$ and encourage financial development further. It can also work to stimulate capital inflows and indirectly reduce the cost of capital in emerging economies.

In the existing literature, Rajan and Zingales (2003) highlight demand as “a prime driver of financial development” and sovereign credit ratings can also indirectly boost demand through the signaling of improved transparency, country risk levels and investor protection. As Rajan and Zingales' (2003) 'private interest group theory' of financial development predicts that incumbents' incentive to oppose financial development will be weaker when a country allows both cross-border trade and capital flows, we interpret that sovereign credit ratings can also provide a mechanism to discourage financially repressive sovereign regimes. In this view, we extend the links known between cross-border transactions and financial market developments from Chinn and Ito (2006) and Bekaert et. al. (2007).

Hence in testing the economic values of different types of sovereign credit ratings, we proceed with our assessment of sovereign ratings on three levels: firstly, on the financial intermediary sector development level; secondly, on the aggregate capital flow level. As Gande and Parsley (2005) highlight "financial flows are now the dominant vehicle of interdependence” (p.692), so by examining the influence of credit ratings on capital flows as part of our analyses, we are contributing to a better understanding of the determinants of capital flows into emerging markets and their interdependence with global financial markets. In this research design, we examine the implications of credit ratings provision for both financial development and aspects of financial integration in emerging market economies.

\footnotetext{
${ }^{3}$ See Boot et al. (2005) for a theoretical discussion on how credit ratings can serve as 'focal points' in financial markets and help to reduce financial fragility.
} 


\section{Data descriptions and modelling issues}

\subsection{Sovereign ratings}

We consider sovereign credit ratings produced by Standard and Poor's (S\&P) on a total of 51 emerging market countries in four regional groupings - Asia, Latin America, Emerging Europe and Africa/Middle East for the period 1995 to 2003 (see Appendix B for country list $)^{4}$. S\&P's sovereign ratings include long-term ratings and their outlooks for the six months hence and short-term ratings for both foreign currency and local currency denominated debt. The long-term ratings range from AAA (highest credit quality) to D/SD (default/selective default) and these ratings are attached with rating outlook that varies from Credit Watch Positive to Credit Watch - Negative. The ratings of BBB- and above are considered investment grade and the ratings $\mathrm{BB}+$ and below are considered speculative. The short-term ratings vary from $\mathrm{A}-1+$ to $\mathrm{D} / \mathrm{SD}$. The investment grade is $\mathrm{A}-3$ and above. The ratings announcements are irregularly spaced and by nature are made only when there are sufficient changes in underlying economic and financial conditions that warrant changes in the credit quality of sovereigns. For instance, out of a total of 15 ratings changes announced for Argentina over the period, 8 were made in 2001 alone (Argentine debt crisis).

The S\&P's ratings are linearly transformed into a time series for each of the countries in two stages, similar to Gande and Parsley's (2005) construction of their comprehensive sovereign credit measure. ${ }^{5}$ First, we assign numerical values for each of the rating grade ranging from 0 for default to 20 for AAA for the long-term ratings and 7 for the top shortterm ratings. Appendix A shows the numerical conversion of the ratings to operationalize statistical analyses. The long-term ratings are adjusted to include the outlook associated with each rating. That is, the long-term ratings series is the sum of long-term rating plus ratings outlook. For instance, if a country's average rating for a year was AA (18) and the associated

\footnotetext{
${ }^{4}$ We also considered equivalent ratings produced by Moodys and Fitch. They produced ratings for fewer sovereigns and at less frequent intervals than S\&P with largely consistent assessments. It has also been documented in the sovereign credit ratings literature that S\&P tends to lead other agencies and are more active (see Brooks et al., 2004; and Gande and Parsley, 2005).Thus, we chose to concentrate on the S\&P ratings alone.

${ }^{5}$ In a different line of investigation, Gande and Parsley (2005) and Ferreira and Gama (2007) use the comprehensive credit ratings measure to examine the spillover effects of one country's sovereign credit rating events to other countries' sovereign debt markets and stock markets respectively.
} 
outlook was Positive (0.25), the overall long-term rating would take the value of 18.25. Second, we calculate the annual average rating for each of the 51 sample countries for the period 1995 to 2003. We first generate four daily time series of ratings (long and short-term for foreign and local currency denominated debt) by assigning the announced ratings values to the days between their announcements and the dates of next ratings events. For instance, Argentina's long-term foreign currency rating was changed from CCC+ with negative outlook to CC with negative outlook on 30 October 2001, and then to SD on 6 November 2001. We assign the value of 0.75 (the sum of 1 for the CC and -0.25 for the negative outlook) for the days between 30 October 2001 and 5 November 2001, and 0 (the value for SD) for 6 November 2001 and beyond. The daily ratings series are then used to calculate annual average ratings for each of the 51 countries. Similar conversions are made for the short-term ratings.

\subsection{Financial market variables}

We investigate the role of sovereign ratings on various measures of financial market developments in emerging market countries. To compute various indicators of financial sector development for emerging countries, data was sourced from the World Bank Development Indicators database (WDI), and the World Bank's Financial Structure and Development Database associated with Beck, Demirguc-Kunt and Levine (2000). ${ }^{6}$ Our sample is from 1995-2003 for our 51 emerging countries.

We consider three segments of the financial system - equity, banking and debt markets - to provide different perspectives of financial development. Within each of the three segments we examine a number of alternative measures of market development. For the stock market, we examine the amount of stock traded measured in value as a percentage of GDP and as turnover ratios and also market capitalization as a percentage of GDP. For the banking sector development measures, we examine the amounts of private credit (loans) by deposit money banks and total amount of domestic credit provided by banking sector both as a

\footnotetext{
${ }^{6}$ This database has since been updated to 2004 for most countries.
} 
percentage of GDP. The debt market measures include private and public bond market capitalization as a proportion to GDP.

\subsection{Control variables}

The country economic controls are independent variables that are customarily used in crosscountry financial development studies that we include to reduce model misspecification errors from the omission of important variables. In our study they also help with evaluating the incremental effects of credit ratings provided by independent rating agencies. The data used for these variables are provided in Appendix $\mathrm{C}$ and are discussed further as part of the empirical model.

We recognize that there is likely to be an endogenous relationship between credit ratings and financial development as with improvements in development will come about better credit ratings. We mitigate the confounding effects of this possibility in our panel estimation framework first by using the initial levels of financial development in each intermediary sector and type of capital flow (proxied by a lag of the dependant variable) to indirectly capture all other precursory influences on financial development.

We also control for various governance issues that may arise during the process of financial development and impact upon international capital flows. We employ the aggregate worldwide governance indicators made available by the World Bank which are designed to measure six dimensions of governance: voice and accountability, political stability, government effectiveness, regulation quality, rule of law and control of corruption. The details of the construction of these measures are to be found in Kauffman et al. (2005). This is one of the most comprehensive compilations of data on governance currently available.

\subsection{International financial flows}

We also investigate the role of sovereign credit ratings on international capital flows to emerging market countries. Foreign direct investment (FDI) flows are measured by net inflows as a percentage of GDP and by the log of net inflows as a part of the balance of 
payment in current US Dollars. International banking flows are measured as the net asset of all Bank for International Settlement (BIS) reporting banks against the emerging market countries under examination, and as net loan granted to the latter by the former. Both are measured in US\$ billions. Lastly, we examine two measures of portfolio investment flows bond and equity market investment inflows both measured in US\$ billions. The FDI and portfolio flows data were obtained from the World Bank WDI database and the international banking flow data were sourced from the BIS.

\section{Empirical model}

The series of panel estimations that we conduct are shown in the model below:

$$
\begin{aligned}
& \text { FINDEV }_{i, t}^{j}=\alpha+\alpha_{\text {lag }} \text { FINDEV }_{i, t-1}^{j}+\alpha_{F C L T} \text { FCLT }_{i, t}+\alpha_{F C S T} \text { FCST }_{i, t}+\alpha_{L C L T} L C L T_{i, t}+\alpha_{L C S T} L C S T_{i, t} \\
& +\sum_{k=1}^{p} \alpha_{k} \text { EconCTRS }_{i, t}^{k}+\sum_{m=1}^{q} \alpha_{m} W_{B G o v}^{m} \\
& \text { CAPFLOW }_{i, t}^{j}=\alpha+\alpha_{\text {lag }} \text { CAPFLOW }_{i, t-1}^{j}+\alpha_{F C L T} F_{C L T} T_{i, t}+\alpha_{F C S T} F_{C S T}+\alpha_{i, t} L C L L T T_{i, t}+\alpha_{L C S T} L_{C S T} \\
& +\sum_{k=1}^{p} \alpha_{k} \operatorname{EconCTRS}_{i, t}^{k}+\sum_{m=1}^{q} \alpha_{m} \text { WBGov }_{i, t}^{m}
\end{aligned}
$$

Where FINDEV are the three financial market development measures for country $i$ and year $t$ ( $j$ = stock market, banking sector and bond market, see Appendix A for details on their respective proxies) and CAPFLOW are the international capital flows variables $(j=$ FDI, bank and portfolio flows) grouped by country, yielding a potential 459 (= 51 times 9) observations. The ratings variables we employ are foreign currency ratings for long- and short-term sovereign debt issues (FCLT and FCST), and local currency sovereign debt for long (LCLT) and short-term (LCST). The long-term ratings variable varies between 20 (highest quality) and 0 (current default), whereas the short-term rating take the values between 7 (highest quality) to 0 (current default).

We anticipate that, in general, the sovereign credit rating variables (both in local and foreign currencies) should have a positive influence (i.e. positive ratings coefficients) on the 
financial market developments and capital inflows. This is because of the important leadership role governments play in the early stages of market development in many emerging market countries. In some circumstances, governments’ fiscal positions can play a crucial role in providing various financial and non-financial safety nets to companies that are considered to be of some national significance. As such, governments' fiscal positions would then be seen as one of the indicators of market development potential. In the same spirit, we expect a generally positive influence of high ratings on international capital flows for similar reasons.

A typical feature of emerging markets is a lack of an external financial market in their own currencies leading to the situation of 'original sin' where countries are forced to borrow in hard currencies to finance domestic developments due to insufficient domestic savings ${ }^{7}$. In such a circumstance sovereign credit rating in foreign currencies would play a crucial role in determining to what extent external financing of domestic economic development is facilitated through this channel. Sovereigns are capable of generating local currency funds via issuance of securities or taxation and so default is thought to be unlikely. However, to the extent that some sovereigns have shown tendencies to monetize their national debt leading to inflationary pressures, domestic currency credit ratings would reflect this inflation risk among others. Thus, local currency ratings maybe regarded as a proxy for such an inflation risk rather than sovereign's default risk.

As for short- and long-term ratings, they may convey different risks, liquidity and inflation/default, respectively.

Depending on the types of market development measures, international capital flows, and specific ratings variables considered, we expect some degree of heterogeneity in responses to the ratings variables. In summary, the sign of the coefficient on credit rating history is expected a priori to have a positive sign. We are interested in the differences in magnitude and significance across financial sectors.

The control variables (CONTROLS) employed in the panel regressions varied depending on the financial sector development measures considered and the nature of

\footnotetext{
${ }^{7}$ For more detailed discussion on the idea of original sin, see Eichengreen et al (2002) and McKinnon and Schnabl (2004).
} 
international capital flows. It needs to be pointed out at the outset that there is potentially a long list of economic and financial market variables that could potentially help explain the variables of interest. We narrow the list by firstly considering those control variables that would be of direct relevance to each of the dependant variables as suggested by the literature and then eliminating those that turned out to be insignificant.

For the stock market development measures, we first considered the following control variables - real GDP growth rates, annual percentage change in S\&P/IFC’s investible index, and annual consumer price inflation rate. For the banking sector development measures, we employed interest rate spread (lending rate minus deposit rate) and the ratio of bank liquid reserves to bank assets. For the bond market, we utilized the consumer inflation rate, gross fixed capital formation as a percentage of GDP and log of national income. Log of income was included as it is well accepted in the literature that economic structures become more complex and financial systems deepen with rising income levels. The inflation rate is included as it affects real rates of return and is associated with inflation uncertainty. This may distort financial decision-making and discourage financial intermediation.

In the international capital flows estimations, we use the share (percentage) of international trade to GDP (economic openness) and stock market capitalization as a proportion of GDP (financial market development) for all three types of international flows. In addition, we employ log of national income for the FDI and banking flows, domestic credit provided by banking sector (\% of GDP) for the banking and portfolio flows, and GDP growth rate for the portfolio flows.

\section{Empirical results}

\subsection{Financial sector development with sovereign credit ratings}

The fixed effects estimations allowing for both individual country and time effects of model (1) are presented in Table $1^{8}$. The results suggest that the sovereign credit ratings

\footnotetext{
${ }^{8}$ In some cases, the random effects estimation was shown to be more appropriate according to the Hausman test. However, the resulting random effects estimations produced qualitatively the same results as the fixed effects estimations reported in Table 1 for consistency.
} 
measures have significant influences on financial sector developments. We find that different measures for individual financial sectors are not always influenced by credit ratings in the same manner as they do capture different aspects of financial development in the three broad financial intermediary sectors. In general, each of the financial market development models performs very well. Total variations of development measures explained vary from the low of $58 \%$ to the high of $98 \%$. There is no evidence for a panel unit root in any of the dependant variables.

We recognize that the willingness of investors to hold sovereign debt captured by a steady provision of relevant credit ratings by independent rating agencies may induce an upward bias into our estimation results. However, credit ratings are clearly also signals for financial decision-making and credit rating agencies also serve a monitoring role as shown by Boot et al. (2006).

Foreign currency long-term ratings show expected positive influence in general, and it is statistically significant for bond market developments. Both private and public bond market capitalization increased with ratings improvements. As sovereign ratings generally act as ceilings for private bond issuers in their foreign currency bond issues, high quality issuers would obtain ratings only as good as their sovereign. To the extent that an elevation in foreign currency ratings would relax this constraint, it provides a further boost to private bond market development. It is shown that a greater impact is exerted on the public bond market. There is no evidence of sovereign ratings' influence on banking sector developments. In the stock market, there is a strong negative relationship between market turnover and foreign currency long-term ratings. This might represent a shift of market activities away from the stock market towards banking and bond sectors as the ratings improve. Foreign currency short-term ratings are significant only for private bond market capitalization and the negative coefficient suggests a significant drop in market capitalization in relation to ratings upgrades. It suggests a switch from long-term to short-term foreign currency financing occurs as short-term ratings improve given long-term ratings.

For the long term local currency ratings, with the exception of the bond markets, positive impact is shown in all cases. A significant rise in stock market turnover and two 
measures of bank lending (private credit and BLENDING) is shown in response to an improvement in the long-term ratings. Interestingly, bond markets reacted negatively to a rating improvement and this suggests a lack of development in the domestic currency denominated bond market in emerging economies, consistent with the well-known 'original sin’ phenomenon. In conjunction with a positive influence of foreign currency long-term ratings discussed above, emerging markets show limited domestic bond market development from within relying instead on an improvement in foreign currency ratings to stimulate externally sourced market growth. This argument is reinforced in the international portfolio flow estimations presented in Table 3.

The short-term local currency ratings consistently deter market development in all financial sectors as information from short-term domestic currency ratings work to induce uncertainty and discourage financial intermediation in the economy. This corroborates with Dellas and Hess (2005)'s finding that financial development is significantly related to the behavior of the second moments of stock return distributions. We also find that the private bond sector is the most sensitive to sovereign credit ratings and its development can be hampered by all types of sovereign credit ratings except long-term foreign currency ones. Taken together, our findings suggest that credit ratings do have long-term information content or signaling effect for encouraging financial development across all financial sectors.

As expected, financial sector development is a persistent process with previous levels of own development measures having significantly positive effects on market development over time in all cases. However, as is indicated by the panel unit root test statistics reported in the last section of Table 1, there is no evidence of either a common or an individual unit root.

The aggregate governance measures have diverse influences on the financial development measures in banking and bond markets. In general, stock market measures are insensitive to the governance measures whilst banking sector development is the most sensitive. For banking sector development, the government effectiveness measure had the expected positive influence on two of the three banking sector development measures. Considering the dominant role governments play in the banking sector in many emerging market economies (via government ownership, policy loan directives, moral suasion, etc.), 
government effectiveness is indeed crucial for banking sector development. This is certainly paramount in the initial stages of financial sector development when bank finance dominates other forms of finance for corporations. Interestingly, political stability and regulation quality measures had a negative influence. This may suggest that as these measures deteriorate, there is a significantly greater reliance on the banking sector over the other market-based segments (i.e. bond and stock markets). In the bond markets, there is an interesting contrast between private and public bond market responses to rule of law and corruption measures. Naturally, investors' confidence in the control of corruption is essential for private debt to flourish and poor control enables the misuse of public power for private gains and hence, the reliance on government debt. Still, the rule of law is important for public debt as investors will evidently choose to deal with private borrowers if they have little confidence in the legal system.

Our economic control variables are also significant as in previous studies on financial development. We find that economic growth encourages the trading of stocks, but not bond market nor banking sector development. Similarly, there appears to be a negative relationship between gross fixed capital formation (GFCF) and bond market development measures. This can be explained by our observation that debt markets and banking sectors are either nonexistent or at very early stages of development in emerging economies that have little or no growth and/or capital investments (low economic development) whereas higher levels of economic growth are associated with emerging markets with more advanced financial systems. However, log of income per capita (LOGINC, as a proxy for national wealth) is important for kick starting the development of private bond markets in emerging economies. Inflation significantly detracts from the development of public bond markets and this is consistent with its ambiguous effects on stocks and negative impact on bond expected returns in the asset pricing literature (see Campbell and Ammer, 1993). Banking sectors in emerging markets are immune from the effects of inflation ${ }^{9}$ and are only affected by interest rate spreads and liquid reserves to asset ratios. Lower interest rate spreads (between lending and borrowing rates) are more conducive for banking sector development as they are intuitively

\footnotetext{
${ }^{9}$ This result was revealed in non-reported estimations that are available upon request from the corresponding author. There is empirical literature to suggest that inflation in emerging markets actually improves banks' profits through increased financial transactions in the economy.
} 
associated with more competitive banking industries. Similarly, lower liquid reserves to asset ratios significantly encourage banking developments (proxied by banking credit) because banks are able to operate with higher efficiency.

Growth in investibility (INVEST, based on S\&P's Investible Index), is a measure of the increasing degree to which stocks can be foreign owned within an emerging market. We find that this is clearly important for stock market development and this is consistent with De Jong and De Roon's (2005) and Bae, Chan and Ng's (2004) inferences on increasing financial market integration with world capital markets.

\subsection{Robustness checks of financial sector development estimations}

We provide a summary of alternative estimations of model (1) in Table 2. The top panel reports the ratings variable coefficients when they are estimated with a one period lag. This is to address the potential problems of endogeniety between the financial development measures and the ratings variables ${ }^{10}$. Although, some coefficients lose significance, an overall picture of the role of the rating variables discussed above remains intact. In the lower panel of Table 2, we report the ratings variable coefficients when they are estimated individually. That is each of the four ratings variables are estimated one at a time in Model (1) and the resulting coefficients are reported. This is to address the potential for multicollinearity amongst the ratings variables. Once again, the qualitative results of the estimations are the same as before. Thus, the results reported in Table 1 seem to be free from endogeneity and multicollinearity concerns and are robust to different model specifications.

\subsection{International capital flows with sovereign credit ratings}

Furthering our linkage of credit ratings provision to financial openness and financial development, we investigate the influence of credit ratings on different types of capital flows

\footnotetext{
${ }^{10}$ The ratings variables often do not change over a number of years and when they do the average value during any given year is used as the ratings value for that year. As such, they are more or less pre-determined to the dependent variables and so endogeneity may not be an issue. This is confirmed by the estimations using the one period lag of the ratings variables.
} 
into emerging markets, namely, foreign direct investment, international banking flows and portfolio flows. The panel regression results are shown in Table $3^{11}$. In short, we find heterogeneous influences of various rating types on different capital flows. Both the FDI and banking flows' models perform well in explaining the variations of the dependent variables used. The adjusted R squares range from $54 \%$ to $86 \%$. However, the portfolio flow models' overall performance is lower with the R squares hovering around $30 \%$. As before, there is no evidence of panel unit root in any of the dependant variables.

Long-term foreign currency ratings have the expected positive influences on all three types of capital inflows and each type reveals at least one significant association. This suggests that we can attribute the role of foreign currency ratings in financial development on their long-term contribution to encouraging all three types of capital flows. On the other hand, short-term foreign currency ratings have a significant dampening effect on the two forms of FDI flows. It appears that an improvement in short-term ratings improves access and encourages emerging sovereigns to concentrate on the short-term end in their international financing needs, thus crowding out long-term financial market activities in the form of FDI.

Local currency ratings, both long- and short-term, are in general, detrimental to all three forms of capital inflows. This suggests that to some extent emerging market countries rely on foreign credits for domestic financing needs and improvements in local currency ratings encourages them to switch to domestic currency financing. A lone exception is a positive influence of short-term rating on portfolio equity flows.

The World Bank governance indices have mixed influences on the capital flow measures depending on the types of indices and capital flows. The FDI flows responded

\footnotetext{
${ }^{11}$ Warnock (2002) suggests that capital flows data have limitations as they are “...designed according to the conventions of balance of payment accounting, they capture only the country of the foreign intermediary, which is not necessarily the country of origin”. Despite this, lack of stock data available for foreign capital holdings generally prevents alternative investigations. There is, however, some limited availability of stock data on foreign capital holdings in the IMF's Coordinated Portfolio Investment Survey (CPIS). It covers the period, 1997 and 2001-2005 for total portfolio investment, equity investment, total debt, long term and short-term debt holdings of foreigners on a number of countries. Hence, we also estimated model 2 with these five foreign capital stock variables against the 51 countries over the period 2001-2003 (consistent with the ratings data period) and the results are qualitatively similar to that reported in Table 3 . This indicates that our use of capital flow data provides a fairly accurate picture of rating effects on cross-border investments. Interested readers may obtain the additional estimation results from the corresponding author.
} 
positively to the rule of law and control of corruption suggesting that transparency in terms of the rules governing business and rare abuses of public power for private interest groups significantly encourages international FDI flows. However, there is some evidence of more FDI flows in response to deteriorating voice and accountability and government effectiveness. This suggests that the lack of civil liberty and public services provision may be viewed by multinationals as opportunities for profitable foreign investment rather than deterrents. In contrast, the banking flows were positively influenced by improved voice and accountability and government effectiveness which benefits local citizens. Not surprisingly, banking flows appear to pick up when there is a decline in the ability of governments to form or implement regulations and policies to promote private sector development (deterioration in regulatory quality). The portfolio flows are, in general, less sensitive to the governance measures perhaps, due to their short-term nature. The regulatory measure is positively related to the bond market flows and the rule of law encourages overall portfolio inflows by almost eight-folds. Consistent with contemporary development philosophies, our empirical evidence points clearly to the dire need for emerging market authorities to focus on making improvements to their legal and institutional framework and to keep corruption at bay in order to attract the international capital flows that are necessary for financial developments.

Consistent with the literature, trade (economic) openness is significantly related to capital flows. However, it only promotes FDI, not bank flows. Interestingly, all three forms of portfolio flows show negative associations. This is somewhat unexpected.

We also find that financial market development (proxied by SMCAP) has a significant positive effect on portfolio equity flows, and national income of recipient country (LOGINC) on net loans from international banks and a relative measure of FDI flows (LFDIBOP)

\subsection{Robustness checks of capital flows estimations}

Table 4 reports the summary of the ratings variables from alternative estimations of Model (2). As in the case of Model (1) estimations, the qualitative results of Model (2) estimations reported in Table 3 remain robust to endogeneity and multicollinearity concerns. 


\section{Conclusions}

We investigated the role of sovereign credit ratings provided by Standard and Poor's on various measures of financial market developments in emerging countries. We also examined the influence of the ratings on international capital flows to these markets. In general, we find that sovereign credit ratings together with various governance perspectives are critical determinants of financial development in different financial sectors within emerging markets.

We find long-term ratings (both foreign currency and local currency denominated) are most important for the development of financial sectors in emerging markets. We find that foreign currency long-term ratings provided the most important impetus for international capital inflows and as a consequence, domestic financial market development. All three forms of capital inflows (FDI, international banking and portfolio) significantly increased as foreign currency long-term ratings of emerging market sovereigns improved. Significant domestic bond market development is found to be positively associated with ratings improvements.

Local currency long-term ratings show conflicting results for emerging markets' financial development and capital flows. It stimulated the developments of domestic stock and banking sectors, but had detrimental impact on international capital flows. This is consistent with a view that many emerging market sovereigns provide safety nets for financial sectors (e.g. lenders of last resort in the banking sector and management of market stabilization funds in stock and bond markets) and an improvement in sovereigns' domestic currency fiscal positions adds to market stability and hence stimulus to market growth. On the other hand, this would lessen the need for sovereigns to look to foreign currency capital inflows in financing domestic currency expenditures as domestic markets develop more domestic currency funds would be supplied.

Another interesting result is the detrimental impact of short-term ratings in both foreign and domestic currency ratings. Improvements in short-term ratings, in general, deter international capital inflows and hamper domestic financial market developments. As shortterm ratings improve, sovereigns are lured away from the more expensive long-term financing alternatives. This weakens long-term markets, and to the extent that emerging markets' lack 
of access to long-term sources of capital contributed to their exposure to hard currency liabilities and eventual financial crises, improvements in short-term ratings would be seen as potential detriments. The obvious implication of this finding is for emerging market policy makers to encourage the provision of public credit ratings for long-term debt denominated in both domestic and foreign currencies.

Thus, we make valuable contributions to the knowledge base of emerging market participants and national and global policy makers alike by providing new empirical evidence of the role of sovereign credit ratings (as a country risk measure) on the degrees of emerging market financial sector development and inward capital flows. 


\section{References}

Afonso, A., 2003, Understanding the determinants of sovereign debt ratings: Evident for the two leading agencies. Journal of Economics and Finance 27(1), 56-74.

Bae, K-H., K. Chan and A. Ng, 2004, Investibility and Return Volatility. Journal of Financial Economics, 71, 239-63.

Beck, T., A. Demirguc-Kunt and R. Levine, 2000, A new database on financial development and structure. Policy Research Paper No. 2147, World Bank.

Beck, T. and R. Levine, 2002, Industry growth and capital allocation: Does having a marketor bank-based system matter? Journal of Financial Economics 64, 147-180.

Beck, T., R. Levine and N. Loyaza, 2000, Financial intermediation and growth: Causality and causes. Journal of Monetary Economics 46, 31-77.

Bekaert, G., C. Harvey, C. Lundblad and S. Siegel, 2007, Global growth opportunities and market integration, Journal of Finance, 62(3), 1081-1137.

Brooks, R., R. Faff, D. Hillier and J. Hillier, 2004, The national market impact of sovereign rating changes. Journal of Banking and Finance 28, 233-250.

Boot, A.W., T.T., Milbourne and A. Schmeits, 2005, Credit ratings as coordination mechanisms. Review of Financial Studies 19, 81-118.

Boyd, J. and B. Smith, 1998, The evolution of debt and equity markets in economic development. Economic Theory 12, 519-560.

Campbell, J.Y. and J. Ammer, 1993, What moves the stock and bond markets? A variance decomposition for long-term asset returns. Journal of Finance 48(1), 3-37.

Cantor, R. and F. Packer, 1996, Determinants and impact of sovereign credit ratings. Federal Reserve Bank of New York Economic Policy Review 2, 37-53.

Carlin, W. and C. Mayer, 2003, Finance, investment and growth, Journal of Financial Economics, 69, 191-226.

Chinn, M.D. and H. Ito, 2006, What matters for financial development? Capital controls, institutions, and interactions. Journal of Development Economics, 81(1), 163-192. 
Claessens, S. and L. Laeven, 2003, Financial development, property rights and growth. Journal of Finance 58, 2401-2436.

De Jong, F. and F. A. De Roon, 2005, Time-varying market integration and expected returns in emerging markets. Journal of Financial Economics,78(3), 583-613.

Dellas, H. and M.K Hess, 2005, Financial development and stock returns: A cross-country analysis. Journal of International Money and Finance, 24, 891-912.

Demirguc-Kunt, A. and V. Maksimovic 2002, Funding growth in bank-based and marketbased financial systems: evidence from firm-level data. Journal of Financial Economics 65, 337-363.

Eichengreen, B., R. Hausmann and U. Panizza, 2002, Original sin: the pain, the mystery, and the road to redemption, Mimeo (http://www.financialpolicy.org/financedev/hausmann2002.pdf).

Erb, C.B., C.R. Harvey and T.E. Viskanta, 1999, New perspectives on emerging market bonds: Looking beyond the current crisis. Journal of Portfolio Management 25, 83-92.

Ferreira, M.A. and P.M., Gama, 2007. Does sovereign debt ratings news spill over to international stock markets? Journal of Banking and Finance, forthcoming.

Fisman, R. and L. Love, 2004, Financial development and intersectoral allocation: A new approach. Journal of Finance, 59, 2785-2807.

Gande, A. and D.C. Parsley, 2005, News spillovers in the sovereign debt market. Journal of Financial Economics 75, 691-734.

Greenwood, J. and B. Jovanovic, 1990, Financial development, growth, and the distribution of income. Journal of Political Economy 98, 1076-1107.

Kaufmann, D., A. Kraay and M. Mastruzzi, 2005, Governance Matters IV: Governance Indicators for 1996-2004. World Bank Policy Research Working Paper 3630, Washington, D.C.

La Porta, R., F. Lopez-de-Silanes, A. Shleifer and R. Vishny, 1997, The legal determinants of external finance. Journal of Finance 52, 1131-1150.

La Porta, R., F. Lopez-de-Silanes, A. Shleifer and R. Vishny, 1998, Law and Finance. Journal of Political Economy 106, 1113-1155. 
Levine, R., 1997, Financial development and growth: views and agenda. Journal of Economic Literature 35, 688-726.

Levine, R., 2003, Bank-based or market-based financial systems: Which is better? Journal of Financial Intermediation 11, 398-428.

Levine, R. and S. Zervos, 1998, Stock markets, banks and economic growth. American Economic Review 88, 537-558.

McKinnon, R. and G. Schnabl, 2004, The east Asian dollar standard, fear of floating, and original sin, Review of Development Economics 8, 331-360.

Mora, N., 2006, Sovereign credit ratings: Guilty beyond reasonable doubt? Journal of Banking and Finance, 30(7), 2041-2062.

Morgan, D.P., 2002, Rating banks: Risk and uncertainty in an opaque industry. American Economic Review, 92(4), 874-888.

Ndikumana, L., 2005, Financial development, financial structure, and domestic investment: International evidence. Journal of International Money and Finance 24, 651-673.

Rajan, R.G. and L. Zingales, 1998, Financial dependence and growth. American Economic Review 88, 559-586.

Rajan, R.G. and L. Zingales, 2003. The great reversals: the politics of financial development in the twentieth century. Journal of Financial Economics 69, 5-50.

Reinhart, C.M. and K.S. Rogoff, 2004, Serial default and the 'paradox' of rich-to-poor capital flows. American Economic Review 94, 53-58.

Stulz, R. and R. Williamson, 2003. Culture, openness and finance. Journal of Financial Economics 70, 313-349.

Warnock, F. E., 2002, Home bias and high turnover reconsidered. Journal of International Money and Finance 21(6), 795-805.

Wurgler, J., 2000, Financial markets and the allocation of capital. Journal of Financial Economics 58, 187-214. 
Table 1. Panel data estimations for financial sector development, 1995-2003

The panel data specifications are shown below:

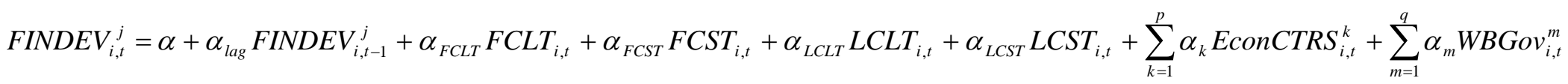

Where FINDEV are the financial market development measures for country $i$ and year $t$ ( $j=$ stock market, banking sector, bond market, see Appendix A for details on their proxies). The ratings variables are foreign currency ratings for long- and short-term sovereign debt issues (FCLT and FCST), and local currency sovereign debt for long (LCLT) and short-term (LCST). The control variables incorporate country-specific governance and fundamental aspects. *, ** and *** denote significance at 10, 5 and 1 percent, respectively. P-values are shown in braces.

\begin{tabular}{|c|c|c|c|c|c|c|c|c|}
\hline & \multicolumn{3}{|c|}{ Stock Market } & \multicolumn{3}{|c|}{ Banking Sector } & \multicolumn{2}{|c|}{ Bond Market } \\
\hline & STRDGDP & STURNOV & SMCAP & PRIVCRED & BANKCRED & BLENDING & PRIVBOND & PUBBOND \\
\hline \multirow[t]{3}{*}{ Lag } & $0.3267^{* * *}$ & $0.4972^{* * *}$ & $0.1786^{* *}$ & 0.8006 & 0.7456 & 0.1249 & $0.5251^{* * *}$ & 0.7819 \\
\hline & $\{0.0000\}$ & $\{0.0000\}$ & $\{0.0202\}$ & $\{0.0000\}$ & $\{0.0000\}$ & $\{0.0752\}$ & $\{0.0000\}$ & $\{0.0000\}$ \\
\hline & \multicolumn{8}{|c|}{ Ratings Variables } \\
\hline \multirow[t]{2}{*}{$\overline{\text { FCLT }}$} & -0.7833 & $-13.0853^{* * *}$ & 0.9923 & -0.2358 & 0.5482 & -0.2316 & $1.0863^{* *}$ & 1.1710 \\
\hline & $\{0.7678\}$ & $\{0.0037\}$ & $\{0.6367\}$ & $\{0.7167\}$ & $\{0.5269\}$ & $\{0.4438\}$ & $\{0.0248\}$ & $\{0.0094\}$ \\
\hline \multirow[t]{2}{*}{ FCST } & -1.2554 & -5.1919 & 2.9846 & 1.0110 & 1.6602 & 0.1244 & $-1.5176^{* *}$ & -1.2017 \\
\hline & $\{0.7748\}$ & $\{0.4835\}$ & $\{0.4244\}$ & $\{0.2268\}$ & $\{0.2561\}$ & $\{0.8238\}$ & $\{0.0292\}$ & $\{0.1397\}$ \\
\hline \multirow[t]{2}{*}{ LCLT } & 2.9612 & $15.8229^{* * *}$ & 0.1403 & $0.8995^{*}$ & -0.0243 & $0.7197^{* * * *}$ & $-0.5054^{*}$ & $-0.5994^{*}$ \\
\hline & $\{0.1699\}$ & $\{0.0000\}$ & $\{0.9363\}$ & $\{0.0787\}$ & $\{0.9732\}$ & $\{0.0096\}$ & $\{0.0914\}$ & $\{0.0673\}$ \\
\hline \multirow[t]{3}{*}{ LCST } & $-13.8501^{* * *}$ & -4.4726 & $-11.8254^{* * *}$ & -0.2875 & $-2.9348^{* *}$ & -1.0720 & $-1.2504^{* *}$ & -1.0858 \\
\hline & $\{0.0014\}$ & $\{0.5319\}$ & $\{0.0023\}$ & $\{0.6635\}$ & $\{0.0118\}$ & $\{0.0379\}$ & $\{0.0103\}$ & $\{0.1285\}$ \\
\hline & \multicolumn{8}{|c|}{ Economic Control Variables } \\
\hline \multirow[t]{2}{*}{ GROWTH } & $0.9280^{* *}$ & 1.0206 & -0.3740 & $-0.4815^{* * *}$ & $-0.4194^{* * *}$ & -0.0123 & $-0.2462^{* * *}$ & $-0.2842^{* * * *}$ \\
\hline & $\{0.0382\}$ & $\{0.1767\}$ & $\{0.3170\}$ & $\{0.0000\}$ & $\{0.0021\}$ & $\{0.8161\}$ & $\{0.0000\}$ & $\{0.0000\}$ \\
\hline \multirow{2}{*}{ INVEST } & 0.0135 & 0.0375 & $0.1423^{* * * *}$ & & & & & \\
\hline & $\{0.6556\}$ & $\{0.4626\}$ & $\{0.0000\}$ & & & & & \\
\hline \multirow[t]{2}{*}{ INFLA } & 0.0088 & -0.1559 & 0.0078 & & & & 0.0756 & -0.0986 \\
\hline & $\{0.9553\}$ & $\{0.5562\}$ & $\{0.6847\}$ & & & & $\{0.0886\}$ & $\{0.0105\}$ \\
\hline \multirow[t]{2}{*}{ INTSPREAD } & & & & $-0.1135^{*}$ & 0.0948 & 0.0210 & & \\
\hline & & & & $\{0.0657\}$ & $\{0.2144\}$ & $\{0.4227\}$ & & \\
\hline \multirow[t]{2}{*}{ LIQTOASSET } & & & & -0.0290 & $-0.3102^{* * *}$ & -0.0653 & & \\
\hline & & & & $\{0.7083\}$ & $\{0.0088\}$ & $\{0.1071\}$ & & \\
\hline GFCF & & & & & & & $-0.6146^{* *}$ & $-0.7585^{* *}$ \\
\hline & & & & & & & $\{0.0135\}$ & $\{0.0163\}$ \\
\hline LOGINC & & & & & & & $13.1895^{* *}$ & 11.0779 \\
\hline & & & & & & & $\{0.0330\}$ & $\{0.1613\}$ \\
\hline
\end{tabular}


Table 1. Panel data estimations for financial sector development, 1995-2003. - Continued

\begin{tabular}{|c|c|c|c|c|c|c|c|c|}
\hline \multirow{2}{*}{ ACCOUNT } & \multicolumn{8}{|c|}{ World Bank Governance Index } \\
\hline & -2.8584 & 4.1994 & -6.2858 & -0.2328 & 0.4917 & 0.0686 & 0.0594 & 0.4940 \\
\hline & $\{0.7564\}$ & $\{0.7904\}$ & $\{0.4018\}$ & $\{0.8908\}$ & $\{0.8661\}$ & $\{0.9537\}$ & $\{0.9434\}$ & $\{0.6885\}$ \\
\hline \multirow[t]{2}{*}{ POLSTA } & 7.3030 & -1.2190 & 8.1564 & $-3.0106^{* *}$ & -0.1617 & $-2.4901^{* *}$ & -0.7347 & -1.6355 \\
\hline & $\{0.3872\}$ & $\{0.9323\}$ & $\{0.2258\}$ & $\{0.0463\}$ & $\{0.9511\}$ & $\{0.0251\}$ & $\{0.4064\}$ & $\{0.1847\}$ \\
\hline \multirow[t]{2}{*}{ GOVEFFECT } & 13.8797 & 11.1988 & 4.7500 & $6.7485^{* * *}$ & $6.7200^{*}$ & 0.3826 & 0.3892 & 1.2325 \\
\hline & $\{0.3074\}$ & $\{0.6349\}$ & $\{0.6430\}$ & $\{0.0013\}$ & $\{0.0591\}$ & $\{0.7876\}$ & $\{0.7622\}$ & $\{0.5161\}$ \\
\hline \multirow[t]{2}{*}{ REGQLTY } & 4.8019 & -15.3062 & 10.0913 & -1.8620 & $-6.3063^{* *}$ & -0.0484 & 0.9911 & -0.5678 \\
\hline & $\{0.6060\}$ & $\{0.3320\}$ & $\{0.1625\}$ & $\{0.2301\}$ & $\{0.0154\}$ & $\{0.9602\}$ & $\{0.3550\}$ & $\{0.6956\}$ \\
\hline \multirow[t]{2}{*}{ RULELAW } & -25.2162 & -15.3263 & -25.8073 & -0.1782 & 2.7230 & 1.4866 & $-3.0955^{*}$ & $6.0387^{* *}$ \\
\hline & $\{0.1434\}$ & $\{0.5967\}$ & $\{0.0667\}$ & $\{0.9363\}$ & $\{0.4870\}$ & $\{0.3736\}$ & $\{0.0654\}$ & $\{0.0102\}$ \\
\hline \multirow[t]{2}{*}{ CORRUPTION } & 8.1488 & -2.0830 & 2.3874 & 1.9750 & 2.4574 & 0.8577 & $2.9174^{* *}$ & $-5.4635^{* * *}$ \\
\hline & $\{0.5983\}$ & $\{0.9378\}$ & $\{0.8492\}$ & $\{0.3462\}$ & $\{0.4966\}$ & $\{0.5623\}$ & $\{0.0323\}$ & $\{0.0079\}$ \\
\hline \multirow[t]{2}{*}{$\mathrm{R}^{2}$-Adj } & 0.59 & 0.77 & 0.82 & 0.99 & 0.98 & 0.58 & 0.98 & 0.98 \\
\hline & \multicolumn{8}{|c|}{ Panel Unit Root tests } \\
\hline Levin, Lin and Chu's t test & -9.4675 & -19.9823 & -45.0520 & $-18.5898^{* * *}$ & $-38.1365^{* * *}$ & -41.4532 & $-6.0712^{* * *}$ & -10.0360 \\
\hline H0: Common Unit Root & $\{0.0000\}$ & $\{0.0000\}$ & $\{0.0000\}$ & $\{0.0000\}$ & $\{0.0000\}$ & $\{0.0000\}$ & $\{0.0000\}$ & $\{0.0000\}$ \\
\hline ADF Fisher Chi-Sq test & $148.9000^{* * *}$ & $160.5060^{* * *}$ & $156.0060^{* * *}$ & $147.1040^{* * *}$ & $211.6450^{* * *}$ & $104.7900^{* *}$ & $78.6883^{* * *}$ & $73.2741^{* *}$ \\
\hline H0: Individual Unit Root & $\{0.0003\}$ & $\{0.0001\}$ & $\{0.0003\}$ & $\{0.0010\}$ & $\{0.0000\}$ & $\{0.0457\}$ & $\{0.0003\}$ & $\{0.0109\}$ \\
\hline
\end{tabular}


Table 2: Robustness checks of financial sector development estimations

The panel data specifications are shown below:

$$
\begin{aligned}
& \text { FINDEV }_{i, t}^{j}=\alpha+\alpha_{\text {lag }} \text { FINDEV }_{i, t-1}^{j}+\alpha_{F C L T} \text { FCLT }_{i, t-1}+\alpha_{F C S T} \text { FCST }_{i, t-1}+\alpha_{L C L T} L C L T_{i, t-1}+\alpha_{L C S T} L_{C S T}+\sum_{i, t-1}^{p} \alpha_{k} \text { ECOnCTRS }_{i, t}^{k}+\sum_{m=1}^{q} \alpha_{m} W B G o v_{i, t}^{m} \\
& \text { FINDEV }_{i, t}^{j}=\alpha+\alpha_{\text {lag }} \text { FINDEV }_{i, t-1}^{j}+\alpha_{\text {Ratings }} \text { Rating }_{i, t}+\sum_{k=1}^{p} \alpha_{k} \text { EconCTRS }_{i, t}^{k}+\sum_{m=1}^{q} \alpha_{m} \text { WBGov }_{i, t}^{m}
\end{aligned}
$$

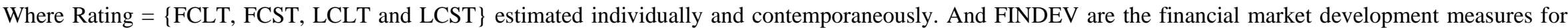

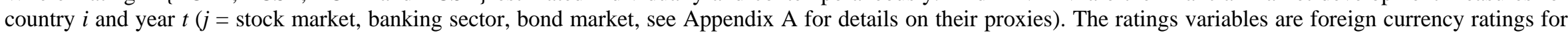

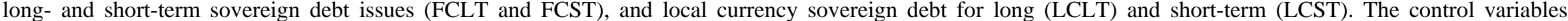

\begin{tabular}{|c|c|c|c|c|c|c|c|c|c|}
\hline & \multicolumn{3}{|c|}{ Stock Market } & \multicolumn{3}{|c|}{ Banking Sector } & \multicolumn{3}{|c|}{ Bond Market } \\
\hline & STRDGDP & STURNOV & SMCAP & PRIVCRED & BANKCRED & BLENDING & PRIVBOND & & PUBBOND \\
\hline & \multicolumn{9}{|c|}{ Model (1a) -One period lag of ratings variables } \\
\hline \multirow[t]{2}{*}{$\mathrm{FCLT}(\mathrm{t}-1)$} & -0.7833 & $-16.3961^{* * *}$ & 0.0857 & -0.9267 & 0.6264 & 0.0136 & 0.7572 & & $0.9244^{* *}$ \\
\hline & $\{0.7678\}$ & $\{0.0001\}$ & $\{0.9653\}$ & $\{0.1522\}$ & $\{0.4484\}$ & $\{0.9626\}$ & $\{0.0848\}$ & & $\{0.0120\}$ \\
\hline \multirow[t]{2}{*}{$\operatorname{FCST}(\mathrm{t}-1)$} & -1.2554 & -9.4111 & -0.8522 & 0.0594 & 0.6179 & 0.5116 & -0.7373 & & -0.9775 \\
\hline & $\{0.7748\}$ & $\{0.1500\}$ & $\{0.8054\}$ & $\{0.9381\}$ & $\{0.6449\}$ & $\{0.3406\}$ & $\{0.2157\}$ & & $\{0.1624\}$ \\
\hline $\mathrm{LCLT}(\mathrm{t}-1)$ & $\{0.1699\}$ & $\{0.0000\}$ & $\{0.6322\}$ & $\{0.0009\}$ & $\{0.9915\}$ & $\{0.4030\}$ & $\{0.0978\}$ & & $\{0.1094\}$ \\
\hline \multirow[t]{3}{*}{$\mathrm{LCST}(\mathrm{t}-1)$} & $-13.8501^{* * *}$ & -1.4842 & 0.0404 & $-1.5396^{* *}$ & $-3.0242^{* * *}$ & -0.4024 & -0.8786 & $*$ & -0.3898 \\
\hline & $\{0.0014\}$ & $\{0.8168\}$ & $\{0.9913\}$ & $\{0.0174\}$ & $\{0.0080\}$ & $\{0.4247\}$ & $\{0.0742\}$ & & $\{0.5804\}$ \\
\hline & \multicolumn{9}{|c|}{ Model (1b) - Ratings variables estimated individually ${ }^{(\mathrm{b})}$} \\
\hline \multirow[t]{2}{*}{ FCLT } & -0.4628 & -1.8458 & 0.3424 & $0.9735^{* * *}$ & 0.0480 & 0.1235 & -0.4417 & $* *$ & 0.0772 \\
\hline & $\{0.6996\}$ & $\{0.4154\}$ & $\{0.7229\}$ & $\{0.0002\}$ & $\{0.8514\}$ & $\{0.1557\}$ & $\{0.0155\}$ & & $\{0.7448\}$ \\
\hline FCST & $\{0.6585\}$ & $\{0.3507\}$ & $\{0.6883\}$ & $\{0.1296\}$ & $\{0.8302\}$ & $\{0.5897\}$ & $\{0.0028\}$ & & $\{0.3598\}$ \\
\hline \multirow[t]{2}{*}{ LCLT } & -0.1862 & $3.5684^{*}$ & -0.2370 & $0.9135^{* * *}$ & 0.3035 & $0.3869^{* * *}$ & -0.4928 & $* * *$ & -0.3794 \\
\hline & $\{0.8730\}$ & $\{0.0811\}$ & $\{0.8017\}$ & $\{0.0000\}$ & $\{0.4332\}$ & $\{0.0037\}$ & $\{0.0063\}$ & & $\{0.1033\}$ \\
\hline \multirow[t]{2}{*}{ LCST } & $-10.3442^{* * *}$ & 3.8226 & $-8.4538^{* * *}$ & 0.7972 & $-2.0654^{* *}$ & -0.0294 & -1.2344 & $* * *$ & $-1.1286^{*}$ \\
\hline & $\{0.0050\}$ & $\{0.5519\}$ & $\{0.0088\}$ & $\{0.1976\}$ & $\{0.0493\}$ & $\{0.9459\}$ & $\{0.0017\}$ & & $\{0.0654\}$ \\
\hline
\end{tabular}
incorporate country-specific governance and fundamental aspects. *, ** and *** denote significance at 10, 5 and 1 percent, respectively. P-values are shown in braces. 
Table 3. Panel regression estimations for capital flows

The panel data specifications are shown below:

CAPFLOW $_{i, t}^{j}=\alpha+\alpha_{\text {lag }}$ CAPFLOW $W_{i, t-1}^{j}+\alpha_{F C L T} F_{C L} T_{i, t}+\alpha_{F C S T}$ FCST $_{i, t}+\alpha_{L C L T} L C L T_{i, t}+\alpha_{L C S T} L_{C S T} T_{i, t}+\sum_{k=1}^{p} \alpha_{k}$ EConCTRS $_{i, t}^{k}+\sum_{m=1}^{q} \alpha_{m} W B G o v_{i, t}^{m}$

Where CAPFLOW are the international capital flow measures for country $i$ and year $t(j=$ FDI, Bank, Portfolio flows see Appendix A for details on their proxies). The ratings variables are foreign currency ratings for long- and short-term sovereign debt issues (FCLT and FCST), and local currency sovereign debt for long (LCLT) and short-term (LCST). The control variables incorporate country-specific governance and fundamental aspects. *, ** and ***, denote significance at 10,5 and 1 percent, respectively. Numbers in braces are p-values.

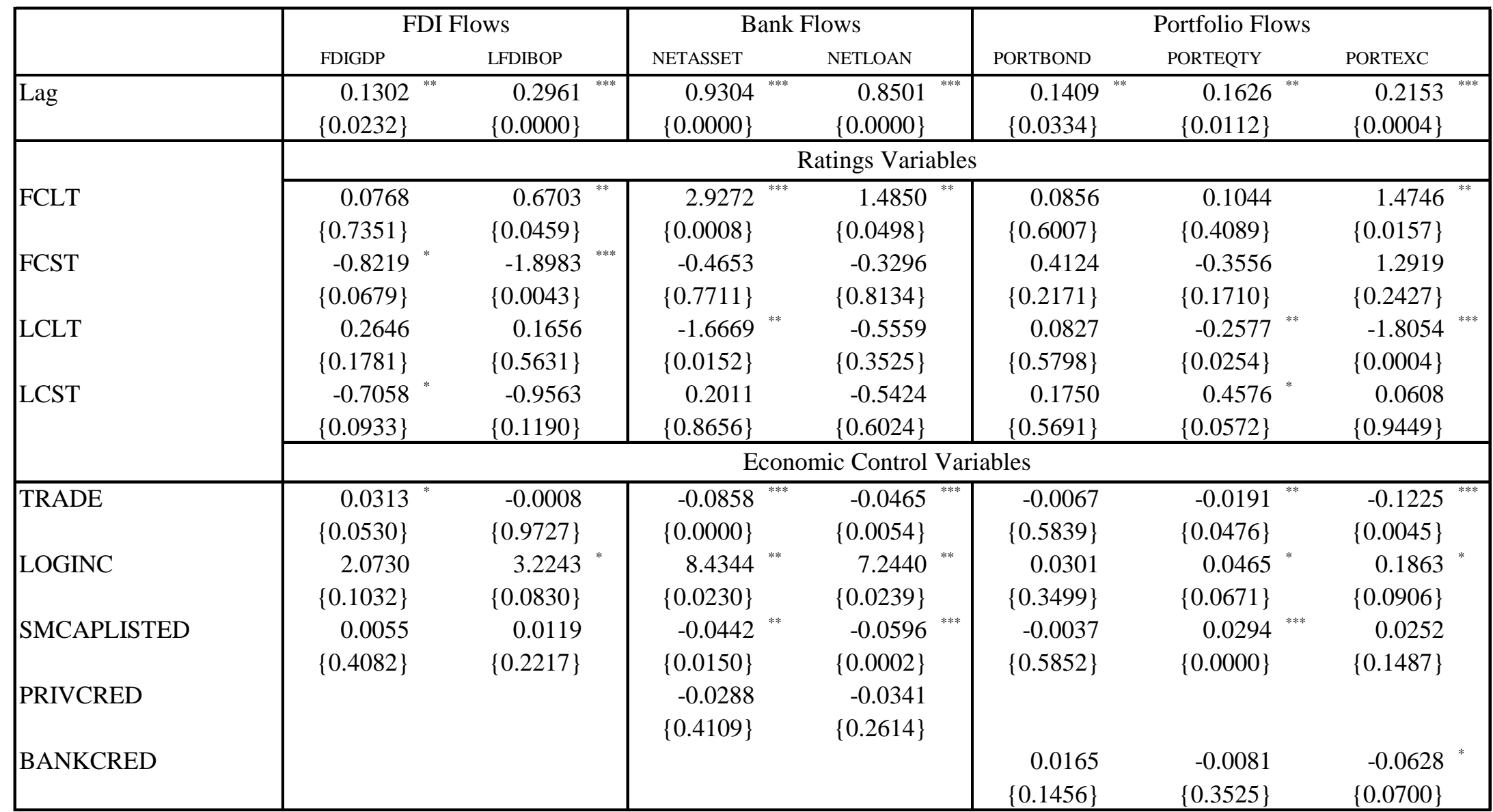


Table 3. Panel regression estimations for capital flows - Continued

\begin{tabular}{|c|c|c|c|c|c|c|c|}
\hline & \multicolumn{7}{|c|}{ World Bank Governance Index } \\
\hline \multirow[t]{2}{*}{ ACCOUNT } & -1.2233 & $-2.8013^{* *}$ & $3.8760^{* *}$ & $3.6432^{* * *}$ & -0.4695 & 0.6971 & -3.7610 \\
\hline & $\{0.1579\}$ & $\{0.0271\}$ & $\{0.0161\}$ & $\{0.0095\}$ & $\{0.4501\}$ & $\{0.1477\}$ & $\{0.1076\}$ \\
\hline \multirow[t]{2}{*}{ POLSTA } & 0.1007 & 0.9172 & -0.9307 & -2.1304 & $-1.0821 *$ & -0.7653 & -1.1915 \\
\hline & $\{0.9027\}$ & $\{0.4497\}$ & $\{0.5537\}$ & $\{0.1228\}$ & $\{0.0827\}$ & $\{0.1128\}$ & $\{0.5929\}$ \\
\hline \multirow[t]{2}{*}{ GOVEFFECT } & $-3.0115^{* * *}$ & $-4.6330^{* * *}$ & $5.5159^{*}$ & 3.8551 & -0.9213 & -0.1801 & -1.0753 \\
\hline & $\{0.0083\}$ & $\{0.0062\}$ & $\{0.0874\}$ & $\{0.1701\}$ & $\{0.2926\}$ & $\{0.7887\}$ & $\{0.7007\}$ \\
\hline \multirow[t]{2}{*}{ REGQLTY } & 0.7971 & 0.6726 & $-4.1712^{* *}$ & $-3.7991^{* *}$ & $1.4338^{* *}$ & -0.0391 & 0.9379 \\
\hline & $\{0.3118\}$ & $\{0.5577\}$ & $\{0.0474\}$ & $\{0.0386\}$ & $\{0.0135\}$ & $\{0.9301\}$ & $\{0.6558\}$ \\
\hline \multirow[t]{2}{*}{ RULELAW } & $4.6132^{* * *}$ & $4.8018^{* *}$ & -4.3672 & -0.1687 & 1.3218 & 1.0347 & $7.8792^{* *}$ \\
\hline & $\{0.0018\}$ & $\{0.0258\}$ & $\{0.2176\}$ & $\{0.9567\}$ & $\{0.2304\}$ & $\{0.2167\}$ & $\{0.0242\}$ \\
\hline \multirow[t]{2}{*}{ CORRUPTION } & 0.4886 & $3.0868^{*}$ & -0.0109 & -1.2594 & -0.4419 & -0.4482 & 0.2543 \\
\hline & $\{0.6873\}$ & $\{0.0830\}$ & $\{0.9975\}$ & $\{0.6736\}$ & $\{0.6188\}$ & $\{0.5142\}$ & $\{0.9278\}$ \\
\hline \multirow[t]{2}{*}{$\mathrm{R}^{2}$-Adj } & 0.54 & 0.73 & 0.86 & 0.84 & 0.30 & 0.38 & 0.27 \\
\hline & \multicolumn{7}{|c|}{ Panel Unit Root tests } \\
\hline Levin, Lin and Chu's t test & $-16.5035^{* * *}$ & $-14.2242^{* * *}$ & $-11.4484^{* * *}$ & $-15.3263^{* * *}$ & $-16.4001^{* * *}$ & $-33.9871^{* * *}$ & $-38.9918^{* * *}$ \\
\hline H0: Common Unit Root & $\{0.0000\}$ & $\{0.0000\}$ & $\{0.0000\}$ & $\{0.0000\}$ & $\{0.0000\}$ & $\{0.0000\}$ & $\{0.0000\}$ \\
\hline ADF Fisher Chi-Sq test & $146.335^{* * *}$ & $139.748^{* * *}$ & $162.817^{* * *}$ & $129.459^{* *}$ & $142.474^{* * *}$ & $203.755^{* * *}$ & $203.129^{* * *}$ \\
\hline H0: Individual Unit Root & $\{0.0018\}$ & $\{0.0054\}$ & $\{0.0001\}$ & $\{0.0345\}$ & $\{0.0000\}$ & $\{0.0000\}$ & $\{0.0000\}$ \\
\hline
\end{tabular}


Table 4: Robustness checks of capital flows estimations

The panel data specifications are shown below:

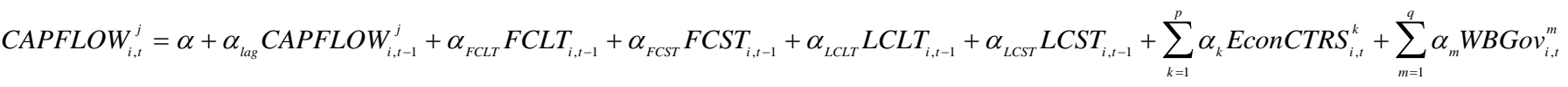

$$
\begin{aligned}
& \text { CAPFLOW }_{i, t}^{j}=\alpha+\alpha_{\text {lag }} \text { CAPFLOW }_{i, t-1}^{j}+\alpha_{\text {Ratings }} \text { Rating }_{i, t}+\sum_{k=1}^{p} \alpha_{k} \text { EConCTRS }_{i, t}^{k}+\sum_{m=1}^{q} \alpha_{m} \text { WBGov }_{i, t}^{m}
\end{aligned}
$$

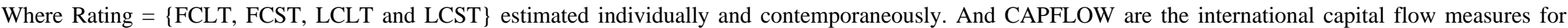

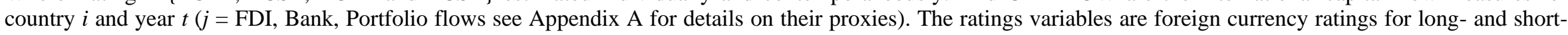

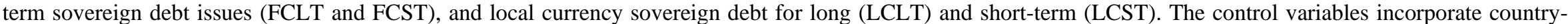
specific governance and fundamental aspects. *,** and *** denote significance at 10, 5 and 1 percent, respectively. P-values are shown in braces.

\begin{tabular}{|c|c|c|c|c|c|c|c|}
\hline & \multicolumn{2}{|c|}{ FDI Flows } & \multicolumn{2}{|c|}{ Bank Flows } & \multicolumn{3}{|c|}{ Portfolio Flows } \\
\hline & FDIGDP & LFDIBOP & NETASSET & NETLOAN & PORTBOND & PORTEQTY & PORTEXC \\
\hline & \multicolumn{7}{|c|}{ Model (2a) - One period lag of ratings variables } \\
\hline \multirow[t]{2}{*}{ FCLT(t-1) } & 0.2972 & $0.7672^{* *}$ & $2.4740^{* * *}$ & $1.3282^{*}$ & 0.1895 & -0.1008 & $1.4012^{* *}$ \\
\hline & $\{0.1793\}$ & $\{0.0203\}$ & $\{0.0032\}$ & $\{0.0660\}$ & $\{0.2376\}$ & $\{0.4197\}$ & $\{0.0210\}$ \\
\hline \multirow[t]{2}{*}{$\mathrm{FCST}(\mathrm{t}-1)$} & $-0.7671^{*}$ & $-1.6930^{* * *}$ & -0.4313 & -0.6445 & 0.2251 & -0.0289 & 0.3835 \\
\hline & $\{0.0787\}$ & $\{0.0097\}$ & $\{0.7775\}$ & $\{0.6265\}$ & $\{0.4883\}$ & $\{0.9123\}$ & $\{0.7122\}$ \\
\hline \multirow[t]{2}{*}{$\mathrm{LCLT}(\mathrm{t}-1)$} & -0.0446 & -0.2778 & $-1.4855^{* *}$ & -0.4575 & 0.0051 & -0.2005 & $-1.5300^{* * *}$ \\
\hline & $\{0.8148\}$ & $\{0.3187\}$ & $\{0.0211\}$ & $\{0.4112\}$ & $\{0.9705\}$ & $\{0.0610\}$ & $\{0.0017\}$ \\
\hline \multirow[t]{3}{*}{$\operatorname{LCST}(\mathrm{t}-1)$} & -0.5237 & -0.2919 & 0.1151 & -0.7118 & 0.1013 & 0.3538 & -0.0732 \\
\hline & $\{0.2156\}$ & $\{0.6362\}$ & $\{0.9162\}$ & $\{0.4552\}$ & $\{0.7321\}$ & $\{0.1235\}$ & $\{0.9351\}$ \\
\hline & \multicolumn{7}{|c|}{ Model (2b) - Ratings variables estimated individually } \\
\hline \multirow[t]{2}{*}{ FCLT } & -0.0600 & 0.0831 & $1.7721^{* * * *}$ & $1.4338^{* * *}$ & 0.0060 & 0.0444 & 0.3691 \\
\hline & $\{0.6237\}$ & $\{0.6507\}$ & $\{0.0028\}$ & $\{0.0089\}$ & $\{0.9121\}$ & $\{0.3520\}$ & $\{0.2442\}$ \\
\hline \multirow[t]{2}{*}{ FCST } & -0.4947 & $-0.8057^{*}$ & 1.6931 & 1.5097 & 0.0654 & -0.0390 & 0.0204 \\
\hline & $\{0.1007\}$ & $\{0.0732\}$ & $\{0.2507\}$ & $\{0.2642\}$ & $\{0.6717\}$ & $\{0.7728\}$ & $\{0.9661\}$ \\
\hline \multirow[t]{2}{*}{ LCLT } & 0.0077 & 0.0470 & $1.1189^{* *}$ & 0.7261 & -0.0327 & $-0.1628^{* * *}$ & $-0.5006^{*}$ \\
\hline & $\{0.9470\}$ & $\{0.7822\}$ & $\{0.0402\}$ & $\{0.1581\}$ & $\{0.4297\}$ & $\{0.0076\}$ & $\{0.0868\}$ \\
\hline \multirow[t]{2}{*}{ LCST } & -0.4404 & -0.6159 & 1.9065 & 1.6640 & -0.0695 & -0.0403 & -0.7787 \\
\hline & $\{0.1785\}$ & $\{0.2004\}$ & $\{0.1579\}$ & $\{0.1779\}$ & $\{0.5349\}$ & $\{0.8303\}$ & $\{0.3065\}$ \\
\hline
\end{tabular}




\section{Appendix A}

\section{Linear transformation of S\&P's sovereign credit ratings}

\begin{tabular}{|c|c|c|c|}
\hline \multicolumn{2}{|c|}{ Long-term Ratings } & \multicolumn{2}{|c|}{$\underline{\text { Short-term Ratings }}$} \\
\hline Rating & Conversion & Rating & Conversion \\
\hline \multicolumn{4}{|c|}{ Investable grades } \\
\hline AAA & 20 & A-1+ & 6 \\
\hline $\mathrm{AA}+$ & 19 & A-1 & 5 \\
\hline AA & 18 & A-2 & 4 \\
\hline AA- & 17 & A-3 & 3 \\
\hline $\mathrm{A}+$ & 16 & & \\
\hline A & 15 & & \\
\hline A- & 14 & & \\
\hline $\mathrm{BBB}+$ & 13 & & \\
\hline BBB & 12 & & \\
\hline BBB- & 11 & & \\
\hline \multicolumn{4}{|c|}{ Speculative grades } \\
\hline $\mathrm{BB}+$ & 10 & & \\
\hline $\mathrm{BB}$ & 9 & B & 2 \\
\hline BB- & 8 & $\mathrm{C}$ & 1 \\
\hline $\mathrm{B}+$ & 7 & $\mathrm{D} / \mathrm{SD}$ & 0 \\
\hline B & 6 & & \\
\hline B- & 5 & & \\
\hline $\mathrm{CCC}+$ & 4 & & \\
\hline CCC & 3 & & \\
\hline CCC- & 2 & & \\
\hline CC & 1 & & \\
\hline $\mathrm{D} / \mathrm{SD}$ & 0 & & \\
\hline \multicolumn{2}{|c|}{ Outlook for Long-term Ratings } & & \\
\hline Outlook & Conversion & & \\
\hline Credit Watch - Positive & 0.5 & & \\
\hline Positive & 0.25 & & \\
\hline Stable & 0 & & \\
\hline Negative & -0.25 & & \\
\hline Credit Watch - Negative & -0.5 & & \\
\hline
\end{tabular}


Appendix B List of Emerging Market Countries studied

\begin{tabular}{|c|c|c|c|}
\hline Asia & Africa/Middle East & Europe & Latin America \\
\hline China & Egypt & Bulgaria & Argentina \\
Hong Kong & Israel & Croatia & Bolivia \\
India & Jordan & Cyprus & Brazil \\
Indonesia & Kuwait & Czech Republic & Chile \\
Kazahkstan & Lebanon & Estonia & Colombia \\
Korea & Oman & Greece & Dominican Republic \\
Malaysia & South Africa & Hungary & Ecuador \\
Pakistan & & Latvia & El Salvador \\
Philippines & & Lithuania & Guatemala \\
Singapore & & Malta & Mexico \\
Thailand & & Poland & Panama \\
& & Portugal & Paraguay \\
& & Romania & Peru \\
& & Russia & Uruguay \\
& & Slovak Republic & Venezuela \\
& & Spain & \\
& & Turkey & \\
& & Ukraine & \\
\hline
\end{tabular}




\section{Appendix C: Variable Definitions and Data definitions}

\begin{tabular}{|l|l|}
\hline Financial Sector Development measures \\
\hline Stock Market & \\
\hline STRDGDP & Stocks traded, total value (\% of GDP) \\
\hline STURNOV & Stocks traded, turnover ratio (\%) \\
\hline SMCAP & Market capitalization of listed companies at the end of year (\% of GDP) \\
\hline Banking Sector & \\
\hline PRIVCRED & Private credit by deposit money banks to GDP (in \%) \\
\hline BANKCRED & Domestic credit provided by banking sector (\% of GDP) \\
\hline BLENDING & Bank and trade-related lending (PPG + PNG) (NFL, current US\$ billion) \\
\hline Debt Market & \\
\hline PRIVBOND & Private bond market capitalization to GDP (in \%) \\
\hline PUBBOND & Public bond market capitalization to GDP (in \%) \\
\hline Sovereign credit ratings type \\
\hline FCLT & Sovereign credit rating - Foreign currency Long-term rating \\
\hline FCST & Sovereign credit rating - Foreign currency Short-term rating \\
\hline LCLT & Sovereign credit rating - Local currency Long-term rating \\
\hline LCST & Sovereign credit rating - Local currency Short-term rating \\
\hline Economic control variables \\
\hline Own_Lag & One-year lag of financial sector development \\
\hline GROWTH & GDP growth (annual \%) \\
\hline INVEST & S\&P/IFC investable index (annual \% change) \\
\hline INFLA & Inflation, consumer prices (annual \%) \\
\hline INTSPREAD & Interest rate spread (lending rate minus deposit rate) \\
\hline LIQTOASSET & Bank liquid reserves to bank assets ratio \\
\hline GFCF & Gross fixed capital formation (\% of GDP) \\
\hline LOGINC & Natural log of national income using GDP per capita \\
\hline TRADE & Total trade as \% GDP \\
\hline Capital Flows & \\
\hline NETASSET & $\begin{array}{l}\text { Total assets minus total liabilities of BIS reporting banks against individual } \\
\text { countries (US\$ billion) }\end{array}$ \\
\hline NETLOAN & $\begin{array}{l}\text { Total loan minus total deposits from BIS reporting banks against individual } \\
\text { countries (US\$ billion) }\end{array}$ \\
\hline FDIGDP & Foreign direct investment, net inflows (\% of GDP) \\
\hline FDIBOP & Foreign direct investment, net inflows (BoP, current US\$ billion) \\
\hline PORTBOND & Portfolio investment, bonds (PPG + PNG) (NFL, current US\$ billion) \\
\hline PORTEQTY & Portfolio investment, equity (DRS, current US\$ billion) \\
\hline PORTEXC & $\begin{array}{l}\text { Portfolio investment, excluding Liabilities constituting foreign authorities' reserves } \\
\text { BoP, current US\$ billion) }\end{array}$ \\
\hline
\end{tabular}




\begin{tabular}{|l|l|}
\hline World Bank Aggregate Governance Indicators - ranges from -2.5 to 2.5 \\
\hline Account & Voice and Accountability \\
\hline Polsta & Political Stability \\
\hline Goveffect & Government Effectiveness \\
\hline Regqlty & Regulatory Quality \\
\hline Rulelaw & Rule of Law \\
\hline Corruption & Control of Corruption \\
\hline
\end{tabular}

